\title{
Historical origins of Brazilian relative backwardness
}

\section{ALEXANDRE RANDS BARROS*}

RESUMO: Este trabalho baseia-se em alguns dados para identificar o século XIX como o período em que a economia do Brasil mais ficou atrasada em relação a países como os EUA, Canadá, Nova Zelândia, Austrália e alguns países da periferia da Europa. Para identificar a razão desse atraso, usamos um exercício com dados da imigração para fazer a decomposição das fontes de crescimento da proporção entre o PIB americano e o brasileiro. Os resultados indicam que o capital humano importado foi responsável por $59 \%$ a $88 \%$ deste crescimento total entre 1820 e 1900.

PALAVRAS-CHAVE: Atraso brasileiro; crescimento brasileiro; imigração; desenvolvimento comparativo.

ABSTRACT: This paper relies on some data to identify the $19^{\text {th }}$ century as the major period in which Brazil economy lagged behind some chosen benchmarking countries, as the USA, Canada, New Zealand, Australia and some European periphery countries. To identify the reasons for this an exercise using immigration data was used to make a decomposition of the sources of growth of the proportion of the USA per capita GDP to the Brazilian one. The results indicate that the imported human capital was responsible for $59 \%$ to $88 \%$ of this total growth between 1820 and 1900 .

KEYWORDS: Brazilian backwardness; Brazilian growth; immigration; comparative development. JEL Classification: N10; N11; N16.

\section{INTRODUCTION}

Brazil is still included among developing countries, as its per capita GDP, when corrected for purchasing power parity, ranked at $74^{\text {th }}$ among 178 with available data in the site of World Bank sample. ${ }^{1}$ Its per capita GDP in 2010 was half the

\footnotetext{
* Presidente da Datamétrica Consultoria, Pesquisa e Telemarketing Ltda, e-mail: alexandre.rands@ datametrica.com.br Submetido: 28/Novembro/2013; Aprovado 14/Fevereiro/2014.

${ }^{1}$ Data are for 2010 and were extracted from the World Bank website.
} 
one of Portugal, the poorest Western European country, under such measure. Even other Latin American countries such as Uruguay, Argentina and Chile had per capita GDP higher than the one found in Brazil in 2010.

To explain such poor development score from a huge economy as the one of Brazil is still an open question, which needs further study, especially after all recent advances in growth theory. How did one of the most profitable colonies of the modern era ${ }^{2}$ ended up as a poor country in the early $21^{\text {st }}$ century? Answering this question would be an important contribution to a huge literature that addresses a similar question in a more general form: why some countries had developed so much more than others? ${ }^{3}$

There are some recent hypotheses raised by this literature that addresses this problem in general frameworks. Examples are the geographical hypothesis forwarded by authors such as Diamond (1997), Olsson and Hibbs (2005), Acemoglu, Johnson and Robinson (2001), or Ashraf and Galor (2011 and 2013) and the institutional approach, forwarded by authors such as Acemoglu Johnson and Robinson (2005 and 2012), North (1990) and Engerman and Sokoloff (1997). While, the former stresses that geographical features such as the suitability to agricultural development or European settlements are major determinants of development, the latter argues that the nature of the established institutions are the major determinant of development.

Although these hypotheses can be very enlightening to understand the historical achievements of a specific country, they can miss many particularities that can be relevant on the understanding of its current situation. Therefore, such approaches have to be enriched with studies that come from the particular circumstance of countries to be confronted with their general conclusions. This study fits in this group of necessary approaches, which focus in a particular case to enrich and extend the understanding of the general hypotheses.

A fundamental question to understand Brazilian relative backwardness is to identify when the country lagged behind those that can be settled as potential benchmarks, such as the United States of America, Canada, Australia and New Zealand, all old European colonies, such as Brazil. This paper will forward some data available that can help on such identification. Comparisons, however, will also be extended to some European countries, particularly two kinds of peripheries within this continent in the early expansion of capitalism. They are the Southern periphery, composed by Portugal, Spain and Greece; and the Northern European periphery, including Finland, Sweden, Switzerland and Norway.

Of course these data have serious limitations, as they were only recently calculated and it is always difficult to estimate aggregate variables for a period long back in the past. Nevertheless, they can give an idea when the backwardness started. This is a crucial step on the understanding of the causes of Brazilian poor long term performance.

\footnotetext{
${ }^{2}$ See Furtado (1959, ch. 11).

${ }^{3}$ For a recent survey of this literature, see Spolaore and Wacziarg (2013).
} 
A basic general conclusion is that the major gap between Brazilian per capita GDP and the one of all these benchmarking countries was built in the $19^{\text {th }}$ century, after Brazilian independence. While most of these countries speeded up their growth within that century, Brazilian economy moved very slowly. Then, the empirical finding of this paper challenges the hypothesis of important studies such as the ones forwarded by Prado Jr. (1963) and Novais (1979), who places in the colonial period and the colonial relationship with Portugal the source of Brazilian relative backwardness. ${ }^{4}$ To some extent, Furtado (1959) also share this view when stresses the lack of domestic market built under the colonial framework when explains Brazil relative backwardness.

The paper also relies on some data on immigration and population for the United States and Brazil to shed some additional lights on some economic features of development of these countries in the periods in which there was more departure on the per capita GDP of these two countries. This enhances the understanding of the nature and origins of the Brazilian relative backwardness.

The paper is organized as following. Next section forwards data on the Brazilian relative development to the benchmarking countries by particular periods to which there is data available. It organizes the data in a way that the major periods in which there was further loss of relative development can be easily identified. Third section brings an alternative decomposition of the historical sources of relative backwardness, which can unveil the role of initial differences of per capita GDP in 1500, when the Brazilian colonial history starts. Fourth section brings a simple exercise comparing American and Brazilian per capita GDP in $19^{\text {th }}$ century to address a potential source of loss of relative development in that century and fifth section puts the major conclusions together.

\section{LONG TERM DATA ON PER CAPITA GDP GROWTH}

Before Portuguese colonizers arrived in Brazil, indigenous population had development standards corresponding to the Neolithic era. Hunting and fishing provided most of the necessary source of meals, although there were already some very rudimentary agricultural practices. There was no writing and even the basic arithmetic notions were unknown.

This low technological development level generated a very egalitarian standard of living, but at very low levels, as productivity was quite low. On Maddison (2011) evaluation, this was the one which would generate the minimum standard of living of mankind. His estimations are that it reached a per capita GDP corresponding to US\$ 400.00 per year on US\$ international of 2005 . This value is the same on his estimates for all countries when they were at this maximum potential backwardness. This would cover all Africa within this period, in addition to most of Americas. ${ }^{5}$

\footnotetext{
${ }^{4}$ Vilela (2011) also criticizes their hypothesis.

${ }^{5}$ Aztecs who were settled in what today is mainly Mexico had already writing and even money, which
} 
While Brazilian was living under such standard of living, European societies had already generated better standard of livings, even in its periphery. Figure 1 brings comparisons on yearly per capita GDP according to Maddison's (2011) estimates. While Brazil, The USA, Australia, New Zealand and Canada all had the US\$ 400.00 minimum standard of living, all European peripheral countries included had already per capita GDP higher than this value, so that the proportion presented in Figure 1 are all equal or over 1.0.

Figure 2 brings this same proportion between per capita GDP in the same countries or group of countries appearing in Figure 1, but estimated for 2008. For all these geographical areas, the proportion presented is over 2.0 and they are often over 3.0. These figures, when compared to those of Figure 1, indicate that all countries or group of them included had grown faster than Brazil between 1500 and 2008. Nevertheless, they do not indicate if it happened along the whole period or in some particular moments.

Table 1 and Figures 3 to 6 bring indexes of proportion of per capita GDPs, between those for benchmarking countries of the two previous figures and those to Brazil. This index was made equal to 100 in year 1500 . Thus, the rate of per capita GDP in any of these countries to the Brazilian one was normalized to be 100 this initial year. This same number which multiplied this value to make it equal to 100 this year was also multiplied by the found ratio in the other years in each of these figures. An average growth rate for each ten years intervals between consecutive years marked in these figures and table were also included to help the data interpretation.

Figure 1: $1500^{\text {th }}$ proportion of per capita GDP in selected countries or groups to the Brazilian one (\%)

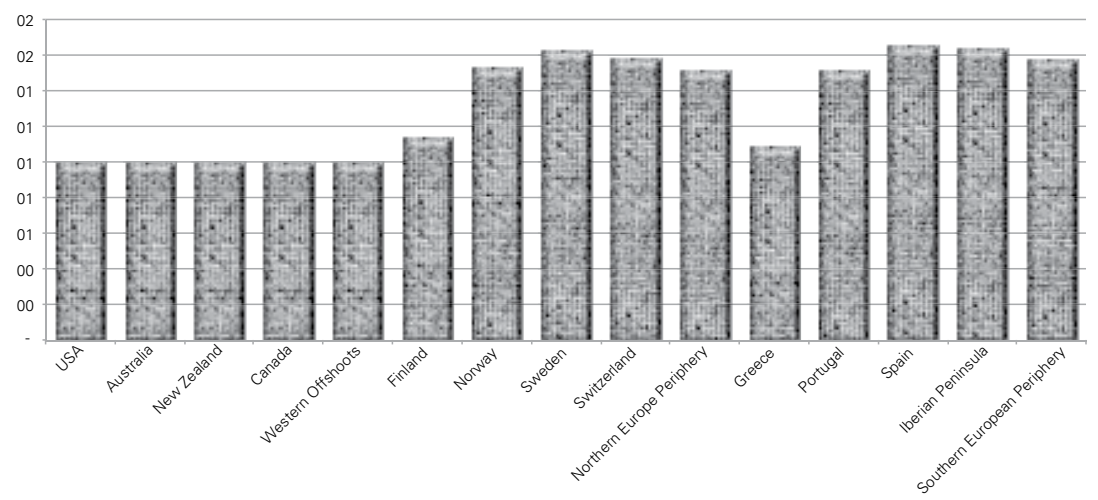

Data on these figures clearly indicate that the $19^{\text {th }}$ century was the one in which the Brazilian economy had the poorest relative performance. Per capita GDP in all benchmarking countries grew faster than the Brazilian one this century. Furthermore this difference was the highest one amongst all periods covered by these table and figures

implies they had basic notions of arithmetic. See Acemoglu and Robinson (2012, p. 50). Nevertheless, Maddison estimation for per capita GDP in Mexico in 1500 was US\$ 425.00, which is already over the minimum absolute standard of living. 
and for all countries. These data definitely indicates that its economic performance in the $19^{\text {th }}$ century is the major responsible for the Brazilian relative backwardness.

Figure 2: 2008 proportion of per capita GDP in selected countries or groups to the Brazilian one (\%)

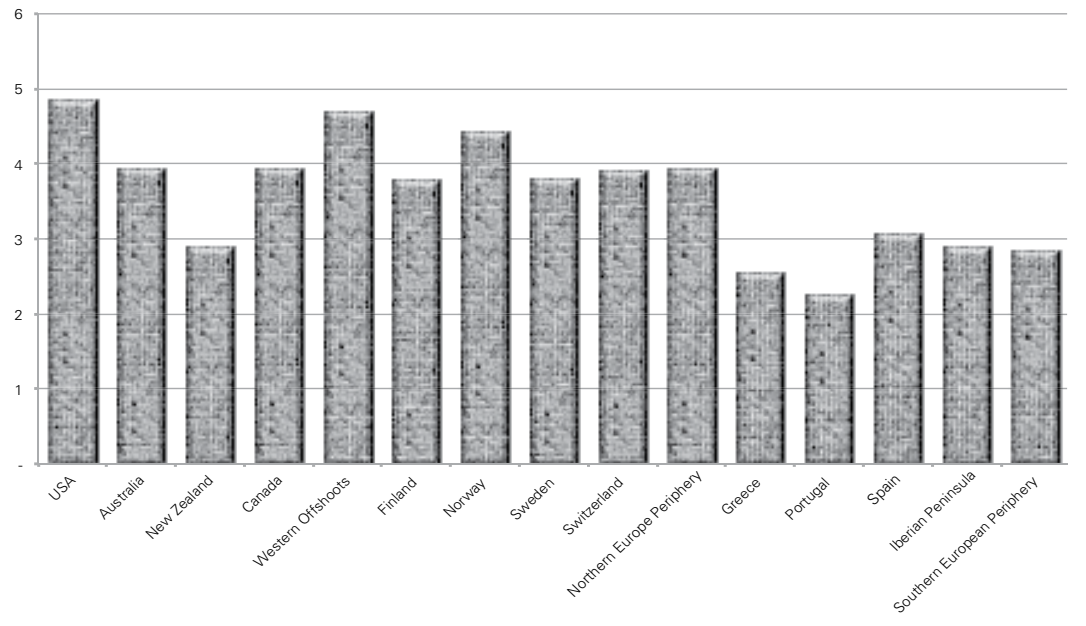

To have a better dimension of the role of the $19^{\text {th }}$ century poor performance on Brazilian relative backwardness, another set of statistics were calculated and presented in Figure 7. They show what would be the proportion of Brazilian per capita GDP to those of the benchmarking countries if it had grown at the same rate as the country under comparison in the $19^{\text {th }}$ century. For all other time intervals growth rates to Brazilian per capita GDP were as calculated from data by Maddison (2011). The actual proportion was also included together with this artificially built proportion, so that comparison and perception of the role of the $19^{\text {th }}$ century is clearer.

The data in Figure 7 show that the $19^{\text {th }}$ century is the only responsible for the Brazilian relative backwardness only when compared to Australia and New Zealand. Canada and the United States had already built a relative advantage in the two previous centuries, but not all that strong. European peripheries had already an advantage in the beginning of Brazilian history and continued to build it in the $20^{\text {th }}$ century, although the buck of their higher relative development had also been built in the $19^{\text {th }}$ century. Therefore, a major question to be answered to understand Brazilian relative backwardness is why Brazil performed all that poorly in the $19^{\text {th }}$ century.

\section{AN ALTERNATIVE DECOMPOSITION OF HISTORICAL SOURCES OF RELATIVE BACKWARDNESS}

Before proceeding to some further analysis that can highlight the source of Brazilian relative backwardness in the $19^{\text {th }}$ century, the simple method pursued in the previous section to identify the major century in which the relative economic backwardness of Brazil to the benchmarking countries emerged will be slightly 


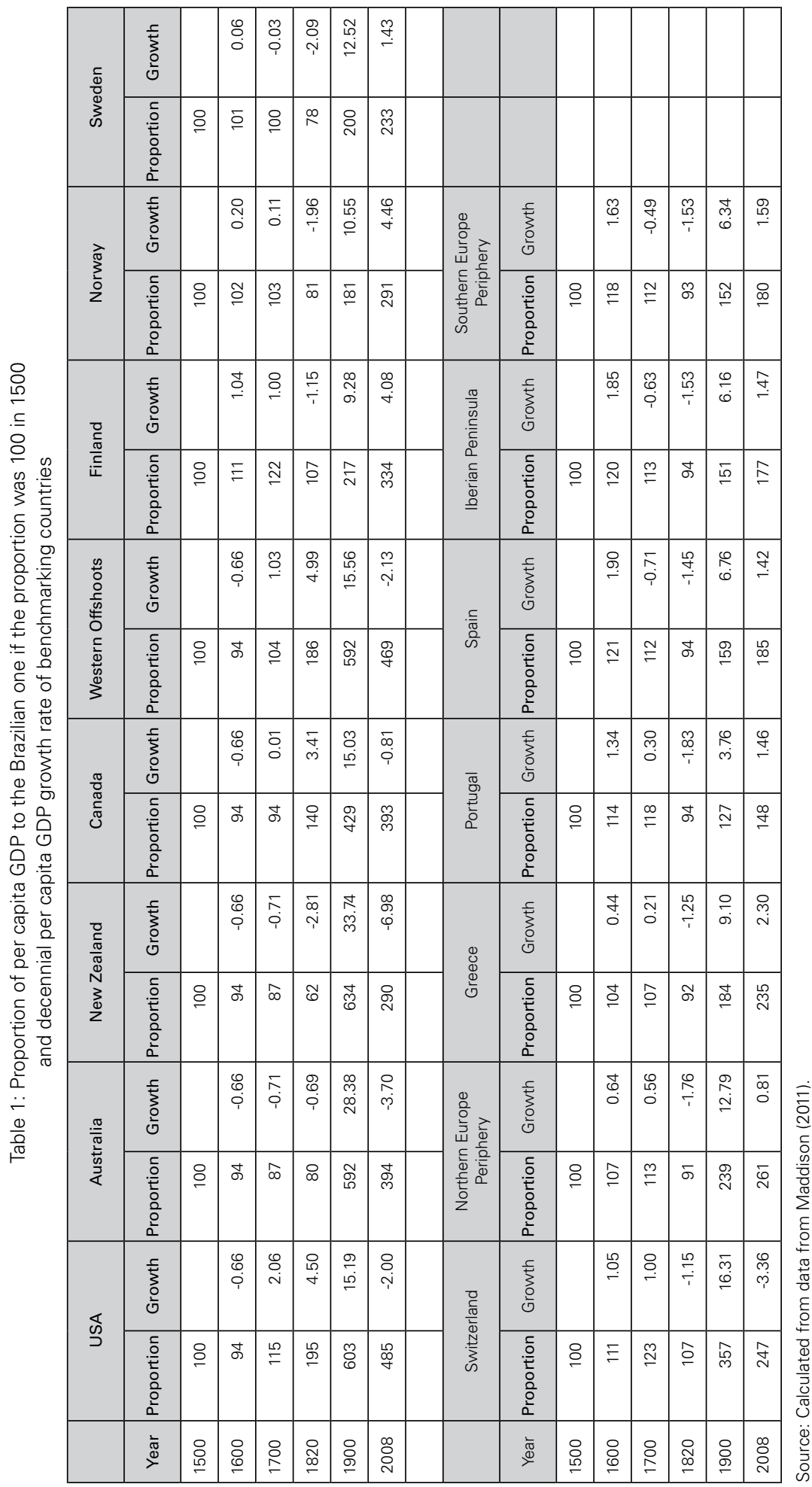



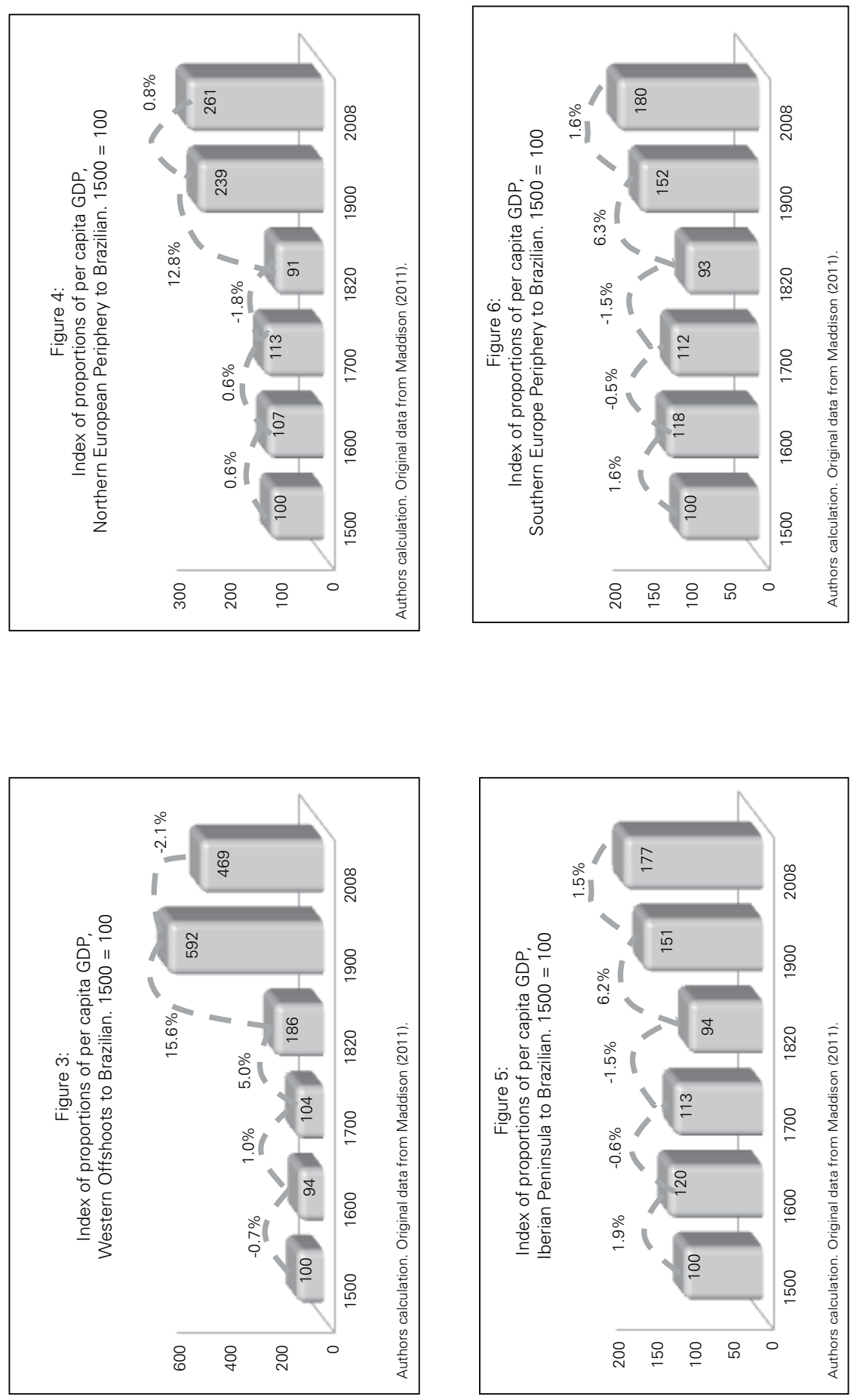
Figure 7:

Proportion of Brazilian to benchmarking countries per capita GDP: Actual in 2008 and simulated with $19^{\text {th }}$ century Brazilian growth rate equal to the one of the other country

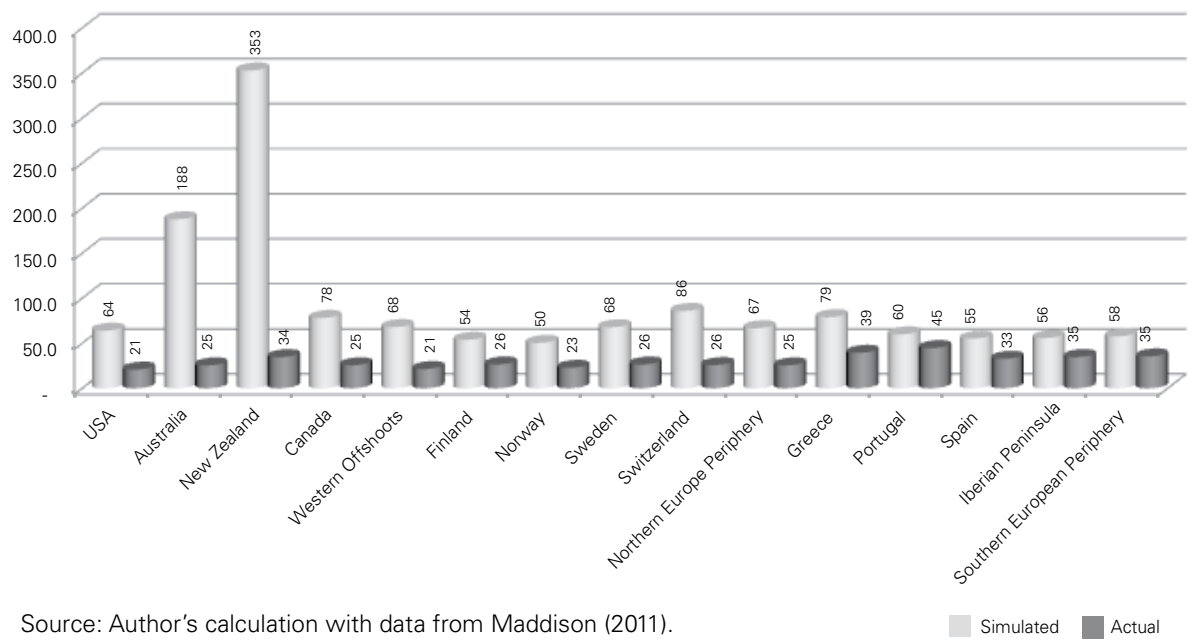

extended to find a measure of the role of each period and the initial differences, altogether. This method can be derived from the simple growth equation:

$$
Y_{f}=Y_{0} \prod_{i=1}^{n}\left(1+g_{i}\right)^{p i}
$$

Where $Y_{f}$ and $Y_{0}$ are the per capita GDP in the last and initial periods, respectively; $g_{i}$ is the yearly growth rate of per capita GDP in period $i$; and $p_{i}$ is the number of years in that same period. There are $\mathrm{n}$ periods between the initial and the last one.

If we divide equation (1) for any benchmarking country by the Brazilian one and take natural logarithm, the result is:

$$
\ln \left(\frac{Y_{f}}{Y_{B f}}\right)=\ln \left(\frac{Y_{0}}{Y_{B 0}}\right)+\sum_{i=1}^{n} p_{i} \ln \left(\frac{1+g_{i}}{1+g_{B i}}\right)
$$

Where $B$ was introduced in the subscripts to identify variables defined to Brazil. If the two sides of equation (2) are divided by the term in the left side, the two sides will be equal to one. Therefore, each term in the right side can be viewed as a proportion of the term in the left side that is explained by the proportion of growth rates in that particular period, or the initial state, in what concerns the first term in the right side.

The proportion of per capita GDP in particular countries to the Brazilian one was decomposed through this method in the role of the initial proportion and the one of growth rates for specific periods selected for years appearing in Table 1. This decomposition appears in Table 2. 


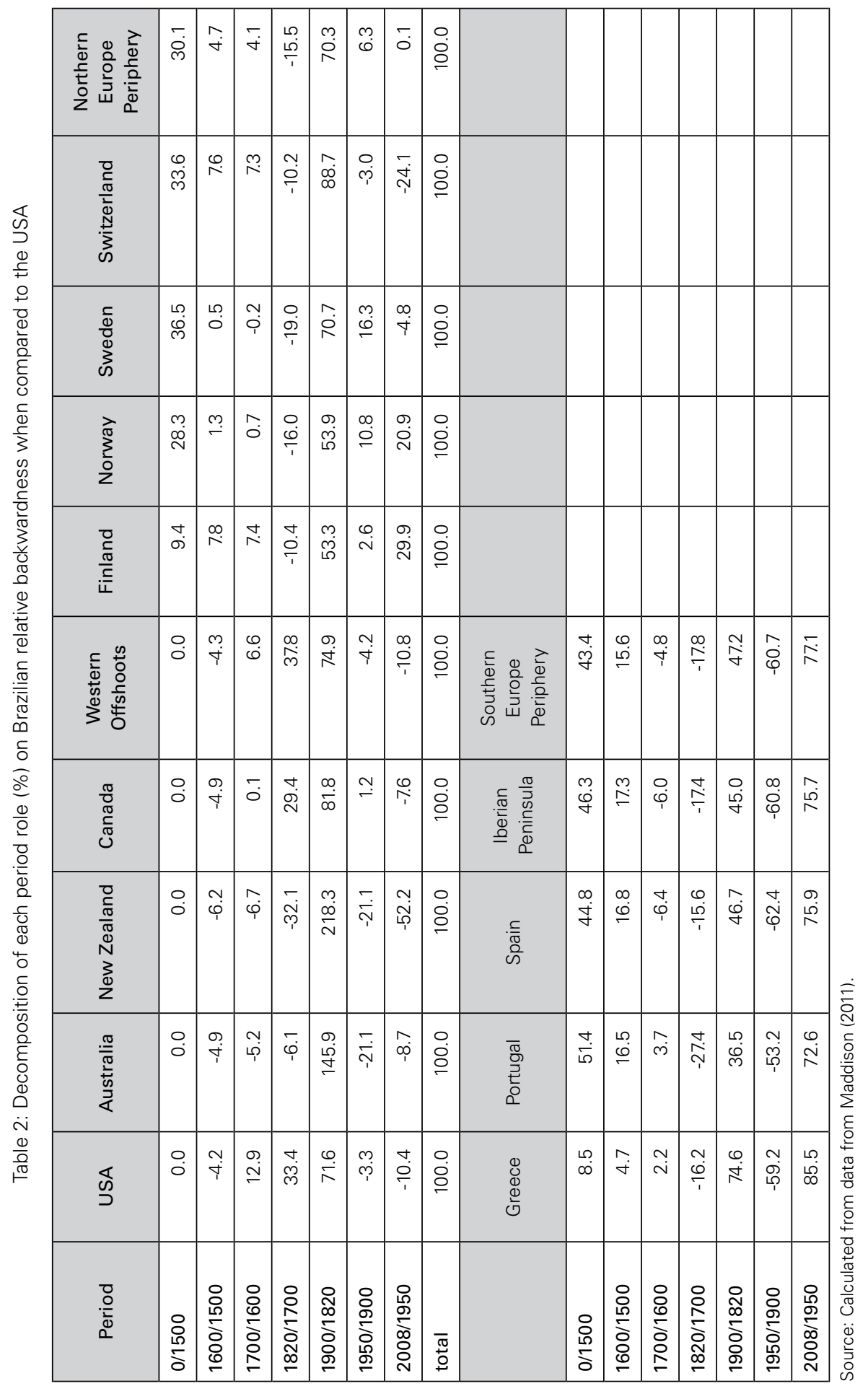


They confirm the prominent role of the $19^{\text {th }}$ century on the Brazilian relative backwardness. For Australia and New Zealand, the $19^{\text {th }}$ century was the determinant. Canada and the USA already outperformed Brazil relevantly in the previous century. The Northern European periphery already started from a higher development level in 1500 , but also had the $19^{\text {th }}$ century as the major determinant of its relative performance. Norway and Finland also had a relevant relative performance in the second half of the $20^{\text {th }}$ century.

European Southern periphery also had the $19^{\text {th }}$ century as a relevant outperformer period, but they all had the second half of the $20^{\text {th }}$ century as the most important period. Portugal and Spain also had the initial period as a very relevant one to explain current relative developments. This means that they also lost relative development in the $19^{\text {th }}$ century relatively to other countries such as the USA and Canada, but they recovered part of it in the second half of the $20^{\text {th }}$ century.

All these statistics confirmed the already pointed role of the $19^{\text {th }}$ century on Brazilian relative backwardness. Its contribution is to place in a better perspective the role of this century with respect to the others and the initial conditions, which are often implicitly taken as the major determinant, as least when comparisons are for European countries. It should be reminded that high performance in the $19^{\text {th }}$ and $20^{\text {th }}$ centuries could be enough to overcome any initial relative backwardness, as the histories of the Unites States, Canada, Australia and New Zealand indicate and the previous data can confirm.

\section{A SIMPLE EXERCISE COMPARING AMERICAN AND BRAZILIAN PER CAPITA GDP}

Brazil has its population formed mainly by three ethnical groups, native Indians, Africans and Europeans. Until the $19^{\text {th }}$ century, Portuguese were the main Europeans who migrated to Brazil. In 1872, year of a census in Brazil, there were 3.7 millions of European descendants in Brazil, $80 \%$ of them of Portuguese origin. In addition there were 1.9 millions of African descendants and 4.1 millions of ethnically mixed people, including natives and their mixtures. ${ }^{6}$ These numbers implied that $38 \%$ of the Brazilian population was formed by European descendants. In 1900, Maddison (2011) estimated that the share of European born or their descendants reached $44 \%$ of the Brazilian population. According to Census data, $7.3 \%$ of the population that year was foreign born, most of them from Europe.

The United States, in its turn, had $88.1 \%$ of its population as European descendants in 1900, according to data by Maddison (2011). Our own estimations as described in appendix are that this number reached $84 \%$. They were spread among many nationalities, but they are mainly from United Kingdom, Ireland and Germany. England, Scotland and Wales together responded for $44 \%$ of the population origin, while Irish responded for $14.1 \%$ and Germans for $14.9 \%{ }^{7}$

\footnotetext{
${ }^{6}$ Data are from IBGE, 1872 Census.

${ }^{7}$ These figures were built from immigration data from 1820 to 1900 extracted from Dillingham (1911)
} 
Two important relationships arise from these figures. Firstly, the proportion of European descendants was much higher in the United States than in Brazil. The former was actually double the latter. This by itself could generate a great difference on per capita GDP in 1900, as pointed by some recent studies on the role of European descendants on development. ${ }^{8}$

In addition to this difference in European descendants, Brazilians had mainly Portuguese as their European ascendants, while the North Americans had English and Germans as their major ascendants in 1900. The United Kingdom had a per capita GDP that was 3.5 times the one prevailing in Portugal in 1900, according to data by Maddison. Germany, on its turn, had a per capita GDP that was 2.3 times the one of Portugal. These differences on the development of the original population who migrated to these two countries could have some role on the relative development reached by them.

In the $19^{\text {th }}$ century there was a sizeable migration from Europe towards the United States, Australia, New Zealand and Latin American countries, such as Argentina, Brazil, Uruguay and Chile. ${ }^{9}$ Before this century such migration was restricted to few origins, such as England, Portugal, Spain and France. Within this century, there was some diversification, with Germans, Italians and Nordic citizens also playing a major role. Altogether, a simple estimation procedure indicates that the Western Europe, formed by 30 nations on Maddison (2011) concept, lost through migration $11.2 \%$ of its population between 1820 and $1900 .{ }^{10}$ This was possible because countries like Brazil, United States, Australia, New Zealand, among others such as Argentina, Chile and Uruguay, were opened to European migrants. The United States, however, was the major destiny, especially for Northern European emigrants.

It is important to stress that European born population could return to their home countries if it was their wishes. Therefore, their migration implied that they could improve their standard of living when reaching their destiny or at least to keep it in the same level. Certainly, there were many individual frustrations, as well as positive surprises. However, on the average such relationship probably prevailed, as migrants were rational agents and would not make persistent mistakes. Information on what they would find in their destinations certainly had flown in their country and region of origin. Any systematic errors and adverse mismatch between

and estimates by Meyerink and Szucs (1984) for 1790. Low immigration between 1790 and 1820 made the proportions in the former year to be used for the latter. Natural growth rates of already residents were assumed to be the same for all ethnical groups.

${ }^{8}$ Se, for example, Easterly and Levine (2012) and Putterman and Weil (2010).

${ }^{9}$ The second half of this period, up to 1913, is referred to in the literature as the Age of European Mass Migration. See, for example Abramitzky, Boustan and Erisksson (2012), Chiswick and Hatton (2003) and O'Rourke (2004).

${ }^{10}$ The procedure assumed that natural population growth in Europe reached the same natural growth (excluding immigration) as the one found for US white population in the years of the $19^{\text {th }}$ century. Of course this method is only an approximation and leaves as migration mass death as the one provoked by Irish famine. Nevertheless, it is still a good approximation for the purposes of the paragraph above. 
expected and actually found standard of living would lead to collapses of migration flows and even to reversion of this flow.

Therefore, numbers on migration indicate that it is possible to think that a reasonable model to explain differences in per capita GDP in the $19^{\text {th }}$ century would include as assumption that there was free movement of labor across Europe and some nations such as Brazil, United States, Australia and New Zealand. All these countries had a large share of their population of European origin, who could return to their home countries if it was a rational procedure. Furthermore, they accepted European migrants, although there was some regulation for such. Such regulations, however, were hardly restrictive, as the figures for immigration show. ${ }^{11}$

Such potential population movements should lead to arbitrage between labor markets. Of course, migration costs, imperfect information and risk aversion were obstacles to a perfect arbitrage, but they certainly restricted differences in income per labor unit, when corrected for purchasing power parity. If income for a baker or a brewer in Germany was much lower than it was in Brazil or in the United States, some of the German residents would migrate to these ex-colonies and improve their standard of living. Thus, some equilibrium between their income within the three countries would exist. The Stolper-Samuelson Theorem and factor price equalization strength even further this relationship.

Under such assumption, a very simple exercise was made to try to understand the sources of differences in per capita GDP performance in Brazil and the United States in the $19^{\text {th }}$ century and the found disparity among per capita GDP between these two countries. This exercise took the re-composition of US population by origin, which appears better described in the appendix. ${ }^{12}$ In 1820 and 1900 a surrogated per capita GDP of the United States was estimated as a weighted average of per capita GDP of countries of origin, where the weights were defined by the share of each group in the total population. Per capita GDPs of natives and African descendants were considered to be equal to the average for African countries and their population were estimated from original data by Thornton (2000) and Gibson and Jung (2002).

Similar exercise was made to Brazil, but as data are scarce, all whites were considered to be either Portuguese or Portuguese descendants in both years. For 1820 this is a very good approximation, but it is less accurate for 1900, as there was already much migration of Germans, Italians and Japanese born people in the end of the $19^{\text {th }}$ century. This procedure relied in the fact that in $187280 \%$ of Brazilian European descendants were from Portuguese origin, according to the Census Data of that year. ${ }^{13}$ Under such assumptions, the actual and estimated per capita GDP in the two countries are as shown in Table 3.

\footnotetext{
${ }^{11}$ The United States restricted migrations from South European countries for some periods and Brazil tried to promote with positive policies migration from Northern European countries such as Austrian and Germans.

12 The appendix is not included, but it is available from the author upon request.

${ }^{13}$ Data is from IBGE (1872).
} 
These data indicate that estimations for both Brazil and the United States are good approximations for the actual figures, either in 1820 and in 1900. In 1820 estimated values for both countries are under a $10 \%$ deviations of the actual number. Nevertheless, they fall within a wider interval of the actual figures in 1900 . These results suggest some potential basic conclusions:

I. The hypotheses underlying the estimations, such as free flow of people through the country borders and similar distribution of productive attributes between migrating and non-migrating people on the source country, were reasonable approximations to the prevailing reality at the two dates, 1820 and 1900, for both countries, especially in the first of these years.

II. There possibly existed some other factors determining the growth rate between the two years for both Brazil and the United States, as the figures for 1900 are less accurate. These factors boosted growth divergence between the two countries as the United States grew faster than the imported productive attributes through migration would predict, while they shrunk Brazilian performance.

Table 3: Actual and surrogated per capita GDP in Brazil and the United States 1820 and 1900

\begin{tabular}{|r|l|r|r|r|}
\hline \multirow{3}{*}{1820} & Actual & \multicolumn{1}{c|}{ Brazil } & \multicolumn{1}{c|}{ USA } & \multicolumn{1}{c|}{$\begin{array}{r}\text { Proportion } \\
\text { USA/Brazil }\end{array}$} \\
\cline { 2 - 5 } & Surrogated & 646.11 & $1,257.25$ & 1.95 \\
\cline { 2 - 5 } & Proportion & 587.65 & $1,301.73$ & 2.22 \\
\hline \multirow{3}{*}{1900} & Actual & 1.10 & 0.97 & 6.03 \\
\cline { 2 - 5 } & Surrogated & 678.44 & $4,090.79$ & 3.92 \\
\cline { 2 - 5 } & Proportion & 808.28 & $3,171.11$ & \\
\hline
\end{tabular}

Source: Actual are from Maddison (2011). Surrogated are own estimation by method described in the appendix and the text.

\section{Migration and per capita GDP}

When people migrate, they carry with them many embodied productive attributes. Most of them are nowadays considered human capital. This involves basic education, which determines logic and analytical abilities, as well as discipline, working behavior, abilities to cooperate and for management. In addition, they also carry specific skills, such as how to make specific tasks and generate particular outputs. In addition to these embodied productive attributes, they also can carry with them some valuable goods and even financial assets that could eventually be used as capital. Therefore, migration of people implies also in migration of human and physical capitals.

The higher the per capita income of a country, the higher tend to be the human capital of its population. Therefore, the higher the per capita income of a particular 
country, the higher tend to be the human capital that emigrates with outflows of its population, ceteris paribus. It is common that when the average human capital of a country increases, all social strata have their own human capital elevated, although they can do at distinct increasing rates. This is why there is a positive correlation between embodied human capital embodied in emigration and the human capital and income of a particular country.

Of course, it is possible to have bias on the attributes of emigrating population. For example, it is possible that although the population of a country has on average ten years of schooling, the set of those who emigrated in a particular period had only seven years of schooling. This bias, however, does not eliminate the expectation that the higher the per capita income of a country, the higher tend to be the human capital embodied in its emigration.

The bias on the migrating population, however, can be severe. For example, it is known that Portuguese migrating to Brazil after 1830's were mainly peasants from the Minho Region (North of Portugal). Some crises on the peasantry economy of that region worked as a major motivation for such emigrations. Therefore, if these immigrants had average abilities that were only able to generate per capita income that was $70 \%$ of the Portuguese average and all immigrants within this period came from this region, ${ }^{14}$ the predicted per capita GDP to Brazil in 1900 from the source population would be US\$ 782.81, instead of the US\$ 808.28 appearing in Table 3. This new figure is even closer to the actual figure, departing only $15.4 \%$ of it.

Bias on the embodied human capital of immigrants could also reduce US gap between actual and projected per capita GDP figures appearing in Table 3. If instead all the weighted average as described above, projection relies on the hypothesis that all European descendants living in the United States in 1900 had the English average productive abilities, instead of those of their original countries, the estimated local per capita GDP would be US\$ 4,008.57, which is $98 \%$ of the actual figure. This would happen under two possibilities: (i) if they and their descendants could easily build productive abilities similar to those of English descendants after their arrival in the United States; or (ii) if there was already an upward bias on the average abilities of migrants of other nationalities, when compared to the population of their country of origin.

\section{The potential role of embodied human capital for development differences in $\mathbf{1 9 0 0}$}

All this discussion and data indicates that embodied human capital on migration could have played a relevant role on the growth inequalities between Brazil and the United States. Taken into account that migration to Australia, New Zealand

\footnotetext{
${ }^{14}$ This proportion of Minho's per capita GDP to the average of Portugal is higher than it was reached in the existing statistics for last fifty years. Therefore, it is a conservative assumption.
} 
and Canada were also predominantly of Europeans, as in the Unites States, and that it was strong in the $19^{\text {th }}$ century, this same logic would also apply to these other countries. Migrating population also carried more embodied human capital and this could have led to faster growth in this century.

To have an idea of the role of this hypothesis, it is possible to use a simple metric established from the difference between per capita GDP in Brazil and the Unites States in 1900.

$$
Y_{U S}-Y_{B R}=\left(\bar{Y}_{U S}+D_{U S}\right)-\left(\bar{Y}_{B R}+D_{B R}\right)
$$

Where $Y_{U S}$ and $Y_{B R}$ are the 1900 per capita GDP in the USA and Brazil, respectively. $\bar{Y}_{U S}$ and $\bar{Y}_{B R}$ are the expected per capita GDP, given the average human capital on immigrating populations and their descendants, both in the United States and Brazil, respectively. $D_{U S}$ and $D_{B R}$ are deviations from these expected per capita GDPs to the United States and Brazil, respectively. Equation (3) above was built under the assumption that $Y_{i}=\bar{Y}_{i}+D_{i}$, for $\mathrm{i}=\mathrm{BR}$ or $\mathrm{i}=\mathrm{US}$. $D_{\mathrm{i}}$ is tautologically defined by this relationship so it is necessarily correct.

The deviations $\mathrm{D}_{\mathrm{US}}$ and $\mathrm{D}_{\mathrm{BR}}$ have many potential determinants. They could be bias on the embodied human capital of immigrating population, as discussed above, or the ability of immigrants to replicate their human capital on their herds, which could be different than a one to one relationship on either direction. The level of efficiency of the local financial market and cross border flow of capital also could affect the speed of migrants to reach the optimal capital-labor-natural resources relationships on new enterprises that were necessary to reach their expected income, when immigrated. Therefore, there are many potential sources of such $\mathrm{D}_{\mathrm{i}}^{\prime}$ s.

Eventual deviations from a rational expectation equilibrium, in which a large group of immigrants did not reach their expected income and do not have resources to proceed to an immediate reversion of his/her migration, also could be reached at some particular years, Nevertheless, such deviations would be a short term one, small in size or both. Therefore, it is of minor interest here.

Equation (3) can be rearranged to generate:

$$
\frac{\bar{Y}_{U S}-\bar{Y}_{B R}}{Y_{U S}-Y_{B R}}+\frac{D_{U S}-D_{B R}}{Y_{U S}-Y_{B R}}=1
$$

Equation (3') indicates that it is possible to split the total difference in actual per capita GDP between the United States and Brazil in two components. One that captures the differences in expected per capita GDP, given the profile of immigration and the hypothesis that there is full intergenerational transmission of human capital. The second component is the difference between the two deviations from the predicted per capita GDP in the two countries, as defined above. The division 
by $Y_{U S}-Y_{B R}$ makes equation (3') to generate the proportion of each of these two components on the total inequality found in 1900. Given that Brazilian deviation in 1900 is actually negative, it is possible to split the difference in the second term of the left side of equation ( $3^{\prime}$ ) between the one arising from US deviations and another one emerging from Brazilian deviations. The three components together still would add to $100 \%$. This is the procedure taken to generate the statistics appearing in Table 4.

Two cases are presented in Table 4. One in which there was no bias in the migration and citizens moving would have the average human capital of those remaining in the source country. The second decomposition consider that all migrants to the USA in the $19^{\text {th }}$ century had the same average human capital as the one of England and those Europeans migrating to Brazil would come from Minho and consequently they had average human capital that would be $70 \%$ of the one of Portugal. All these statistics indicate that the major part of the differences between Brazilian and US per capita GDP is explained by the differences in human capital embodied in the immigrants that headed to each of these countries. The share of this difference goes from $69.2 \%$ in the unbiased case to $94.5 \%$ within the biased case. The right number easily lies in between these two assumptions.

\section{The role of embodied human capital for the rise of disparity along the XIX century}

Equation (3) can be dated to generate growth of disparities in per capita GDP between two periods. Then it becomes:

$$
\begin{aligned}
\left(Y_{U S t}-Y_{B R t}\right)- & \left(Y_{U S t-1}-Y_{B R t-1}\right) \\
& =\left(\bar{Y}_{U S t}+D_{U S t}\right)-\left(\bar{Y}_{B R t}+D_{B R t}\right)-\left(\bar{Y}_{U S t-1}+D_{U S t-1}\right) \\
& +\left(\bar{Y}_{B R t-1}+D_{B R t-1}\right)
\end{aligned}
$$

From this equation (4), some simple manipulation yields:

$$
g_{d}=\left(\bar{g}_{U S} w_{U S}-\bar{g}_{B R} w_{B R}\right)+\left(\bar{r}_{U S} p_{U S}-\bar{r}_{B R} p_{B R}\right)
$$

where each of these variables and weights is defined as in Table 5. Equation (5) can be taken as a decomposition of sources of growth of the difference in per capita GDP between the US and Brazil between 1820 and 1900, if the growth rates are taken between these two years.

The results of this decomposition appear in Table 6. They indicate that the role of embodied human capital through migration on the growth of the two countries together between 1820 and 1900 had a role between $59 \%$ and $88 \%$ on the total growth of disparities between these years. Therefore, imported embodied human capital was the major determinant forcing Brazil to lag behind the USA in the $19^{\text {th }}$ century. 


\section{CONCLUSIONS AND ADDITIONAL COMMENTS}

This paper highlighted some important features of Brazilian relative backwardness. The first and more important conclusion was that the $19^{\text {th }}$ century is the historical moment when the roots of the relative backwardness are settled. In this century the gap between per capita GDPs in Brazil and all benchmarking countries widened. Furthermore, it was the period in which they got further apart. Countries such as Australia and New Zealand built all their relative higher development on this century. United States and Canada already brought some of this relative development from the $18^{\text {th }}$ century, but they still built most the gap in the $19^{\text {th }}$ century. Although all European countries already entered the $15^{\text {th }}$ century with higher per capita GDP, they also had the $19^{\text {th }}$ century as the decisive moment to determine their current relative prosperity.

A second important conclusion forwarded by this paper is that migration was strong in the $19^{\text {th }}$ century, mainly between Europe and their ex-colonies in Australia, New Zealand, and ex-American colonies, such as the United States, Canada, Brazil and other Latin American countries, such as Argentina, Chile, Uruguay and Mexico. These migrations were important to shape the relative development reached by these countries in the end of the $19^{\text {th }}$ century. Some simple simulations comparing the role of European migration on the relative development of Brazil and the United States have indicated that under conservative assumptions, this migration could respond for something between $69.2 \%$ and $94.5 \%$ of total disparities emerging in 1900 between these two countries.

Some further empirical estimation also indicated that the growth of the proportion of the USA per capita GDP to the Brazilian one also had the imported human capital responsible for $59 \%$ to $88 \%$ of total. This also means that this variable is the major determinant of the increase in Brazilian relative backwardness in the $19^{\text {th }}$ century. These basic conclusions leave us with two broad hypotheses to understand the Brazilian relative backwardness, especially as it developed in the $19^{\text {th }}$ century. The first one is that the composition of immigration within that century was a major determinant. The second one is that, despite the apparent role of the immigration composition, it was not a relevant cause of the disparities emerging. Under this second hypothesis, the features of immigration distribution could be a consequence of these other factors, rather than the determinant of inequalities itself.

A currently popular hypothesis to explain the relative development performance among nations is the one forwarded by Acemoglu and Robinson (2012) and Acemoglu, Johnson and Robinson (2005). They argue that the relative quality of institutions were the major determinants of current relative per capita income. If this is true, the data analyzed in this paper indicate that the most relevant institutions in the United States on their argument were the migration law and strategy, which limited the access to South and East Europeans, as well as Asians and Africans to the United States in the $19^{\text {th }}$ century, while promoted North European immigration. Certainly, the attractiveness of the United States, as Europeans with more human capital thought they could prosper also had a role on determining 
such migration. The local institutions, such as democracy, access to public schools, land and some public utilities at the moment could be a determinant to assure such perceived potential prosperity.

Table 4: Sources of inequalities in per capita GDP between the United States and Brazil in 1900

\begin{tabular}{|c|c|c|c|c|c|c|}
\hline & \multicolumn{3}{|c|}{ No bias on migration } & \multicolumn{3}{|c|}{$\begin{array}{c}\text { Bias on migration for English } \\
\text { average (US) and Minho's } \\
\text { guessed average (Brazil) }\end{array}$} \\
\hline Variable & $\begin{array}{c}\text { Absolute } \\
\text { value }\end{array}$ & $\begin{array}{l}\text { Calculation } \\
\text { formula }\end{array}$ & $\begin{array}{l}\text { Percentage } \\
\text { with respect } \\
\text { to the actual } \\
\text { difference }\end{array}$ & $\begin{array}{c}\text { Absolute } \\
\text { value }\end{array}$ & $\begin{array}{c}\text { Calculation } \\
\text { formula }\end{array}$ & $\begin{array}{l}\text { Percentage } \\
\text { with respect } \\
\text { to the actual } \\
\text { difference }\end{array}$ \\
\hline $\begin{array}{l}\text { Actual difference of per } \\
\text { capita GDP between the } \\
\text { United States and Brazil }\end{array}$ & $3,412.35$ & $\begin{array}{c}(4,090.79- \\
678.44)\end{array}$ & $100.0 \%$ & 3.412 .35 & $\begin{array}{c}(4,090.79- \\
678.44)\end{array}$ & $100.0 \%$ \\
\hline $\begin{array}{l}\text { Predicted difference of per } \\
\text { capita GDP between the } \\
\text { United States and Brazil, } \\
\text { given the embodied human } \\
\text { capital of immigrants }\end{array}$ & $2,362.83$ & $\begin{array}{c}(3,171.11- \\
808.28)\end{array}$ & $69.2 \%$ & $3,225.76$ & $\begin{array}{c}(4,008.57- \\
782.81)\end{array}$ & $94.5 \%$ \\
\hline $\begin{array}{l}\text { Deviation of predicted di- } \\
\text { fference of per capita GDP } \\
\text { between the United States } \\
\text { and Brazil generated by } \\
\text { the US deviation from its } \\
\text { predicted value }\end{array}$ & 919,68 & $\begin{array}{l}(4,090.79- \\
3,171.11)\end{array}$ & $27.8 \%$ & 82.22 & $\begin{array}{l}(4,090.79- \\
4,008.57)\end{array}$ & $2.4 \%$ \\
\hline $\begin{array}{l}\text { Deviation of predicted } \\
\text { difference of per capita } \\
\text { GDP between the United } \\
\text { States and Brazil genera- } \\
\text { ted by the Brazilian devia- } \\
\text { tion from its predicted value }\end{array}$ & 129.84 & $\begin{array}{l}(808.28- \\
678.44)\end{array}$ & $3.8 \%$ & 104.37 & $\begin{array}{l}(782.81- \\
678.44)\end{array}$ & $3.1 \%$ \\
\hline
\end{tabular}

Source: Own estimations based on data by Maddison (2011), IBGE and Dilligan (1911).

Table 5: Definitions of variables and weights appearing in equation (5)

\begin{tabular}{|c|l|}
\hline Variable/weight & \multicolumn{1}{|c|}{ Definition of variable or weight } \\
\hline$g_{d}=\frac{\left(Y_{U S t}-Y_{B R t}\right)}{\left(Y_{U S t-1}-Y_{B R t-1}\right)}-1$ & $\begin{array}{l}\text { Growth rate of difference on per capita GDP between US and Brazil } \\
\text { within the period } 1820 \text { to } 1900 .\end{array}$ \\
\hline $\bar{g}_{U S}=\frac{\bar{Y}_{U S t}}{\bar{Y}_{U S t-1}}-1$ & $\begin{array}{l}\text { Growth rate of predicted per capita GDP in the US within the period } \\
\text { between 1820 and 1900. }\end{array}$ \\
\hline $\bar{g}_{B R}=\frac{\bar{Y}_{B R t}}{\bar{Y}_{B R t-1}}-1$ & $\begin{array}{l}\text { Growth rate of predicted per capita GDP in Brazil within the period } \\
\text { between 1820 and 1900. }\end{array}$ \\
\hline
\end{tabular}




\begin{tabular}{|c|l|}
\hline $\bar{r}_{U S}=\frac{D_{U S t}}{D_{U S t-1}}-1$ & $\begin{array}{l}\text { Growth rate of unpredicted component of per capita GDP in the US } \\
\text { within the period between } 1820 \text { and } 1900 .\end{array}$ \\
\hline $\bar{r}_{B R}=\frac{D_{B R t}}{D_{B R t-1}}-1$ & $\begin{array}{l}\text { Growth rate of unpredicted component of per capita GDP in } \\
\text { Brazil within the period between 1820 and 1900. }\end{array}$ \\
\hline$W_{U S}=\frac{\bar{Y}_{U S t-1}}{Y_{U S t-1}-Y_{B R t-1}}$ & $\begin{array}{l}\text { Share of predicted US component in 1820 on the difference between } \\
\text { actual difference between US and Brazilian per capita GDP in 1820. }\end{array}$ \\
\hline$W_{B R}=\frac{\bar{Y}_{B R t-1}}{Y_{U S t-1}-Y_{B R t-1}}$ & $\begin{array}{l}\text { Share of predicted Brazilian component in 1820 on the } \\
\text { difference between actual difference between US and Brazilian per } \\
\text { capita GDP in 1820. }\end{array}$ \\
\hline$p_{U S}=\frac{D_{U S t-1}}{Y_{U S t-1}-Y_{B R t-1}}$ & $\begin{array}{l}\text { Share of unpredicted US component in 1820 on the difference between } \\
\text { actual difference between US and Brazilian per capita GDP in 1820. }\end{array}$ \\
\hline$p_{B R}=\frac{D_{B R t-1}}{Y_{U S t-1}-Y_{B R t-1}}$ & $\begin{array}{l}\text { Share of predicted Brazilian component in 1820 on the } \\
\text { difference between actual difference between US and Brazilian per } \\
\text { capita GDP in 1820. }\end{array}$ \\
\hline
\end{tabular}

Source: Built by the author.

Table 6: Decomposition of the role of each component on the total growth of difference on per capita GDP between the US and Brazil within 1820 and 1900

\begin{tabular}{|c|c|c|c|c|c|c|}
\hline & \multicolumn{3}{|c|}{ Unbiased migration } & \multicolumn{3}{|c|}{$\begin{array}{c}\text { Biased migration for } \\
\text { English (US) } \\
\text { and Minho's (BR) }\end{array}$} \\
\hline Decomposition & Value & Weight & Share & Value & Weight & Share \\
\hline Growth of actual difference & 4.58 & & & 4.58 & & \\
\hline Growth of US predicted component & 1.44 & 2.13 & 0.67 & 1.97 & 2.21 & 0.95 \\
\hline Growth of Brazilian predicted component & 0.38 & 0.96 & 0.08 & 0.33 & 0.96 & 0.07 \\
\hline Growth of US unpredicted component US & -21.68 & -0.07 & 0.34 & -1.89 & -0.15 & 0.06 \\
\hline Growth of Brazilian unpredicted component & -3.22 & 0.10 & -0.07 & -2.79 & 0.10 & -0.06 \\
\hline \multicolumn{7}{|l|}{ Aggregated components } \\
\hline Growth of predicted values & & & 0.59 & & & 0.88 \\
\hline Growth of unpredicted components & & & 0.41 & & & 0.12 \\
\hline
\end{tabular}

Source: Own estimations based on data by Maddison (2011), IBGE and Dilligan (1911).

Although there was also tentative to promote North European immigration in Brazil and some other Latin American countries, such as Argentina, Chile and Uruguay, especially from Germany, there was not such restriction on other sources of migrants. Spaniards, Portugueses and Italians, from a more developed Southeast European country, were also welcomed in these countries. This would be difficult to a country which was colonized by Portugal or Spain, South European countries, to restrict these migrations. Nevertheless, local institutions, which restricted access to land and the low quality of urban infrastructures certainly played a major role. 


\section{REFERENCES}

Abramitzky, R., L. Boustan and K. Erisksson, "Europe's Tired, Poor, Huddled Masses: Self-Selection and Economic Outcomes in the Age of Mass Migration," American Economic Review, 102(5): 1832-1856, 2012.

Acemoglu, D., S. Johnson and J. Robinson, “The Colonial Origins of Comparative Development: An Empirical Investigation,” American Economic Review, 91(5): 1369-1401, 2001.

Acemoglu, D., S. Johnson and J. Robinson, "Institutions as a Fundamental Cause of Long-Run Growth," in P. Aghion and S. Durlauf (eds.), Handbook of Economic Growth, Amsterdam: Elsevier, 2005.

Acemoglu, D. and J. Robinson, Why Nations Fail, New York: Crown Business, 2012.

Ashraf, Q. and O. Galor, "Dynamics and Stagnation in the Malthusian Epoch," American Economic Review, 101(5): 2003-2041, 2011.

Ashraf, Q., and O. Galor, “The 'Out-of-Africa' Hypothesis, Human Genetic Diversity, and Comparative Economic Development.” American Economic Review 103 (1): 1-46, 2013.

Chiswick, Barry and Timothy J. Hatton, "International Migration and the integration of Labor Markets," in Michael D. Bordo, Alan M. Taylor and Jeffrey G. Williamson (eds.), Globalization in Historical Perspective, Chicago: University of Chicago Press, 2003.

Diamond, P., "Guns, Germs, and Steel: The Fates of Human Societies,” New York: Norton, 1997.

Dillingham, W., Statiscal Review of Immigration 1820-1910, Washington: Government Printing Office, 1911.

Easterly and Levine, “The European Origins of Economic Development," Cambridge, Mass., NBER Working Paper, \# 18162, 2012.

Engerman, S. and K. Sokoloff, "Factor Endowments, Institutions, and Differential Paths of Growth among New World Economies: A View from Economic Historians of the United States," in S. Haber (ed.), How Latin America Fell Behind: Essays on the Economic History of Brazil and Mexico, 1800-1914, Stanford: Stanford University Press, 1997.

Furtado, C., Formação Econômica do Brasil, São Paulo: Editora Nacional, 1959.

Gibson, C. and K. Jung, "Historical Census Statistics on Population Totals By Race, 1790 to 1990, and By Hispanic Origin, 1970 to 1990, for The United States, Regions, Divisions and States," US Census Bureau, Working Paper \# 56, 2002.

IBGE, Censo demográfico de 1872 no Brasil, Rio de Janeiro: IBGE, 1872.

Maddison, A., The World Economy: A Millenial Perspective, Paris: OECD 2001.

Maddison, A., Historical Statistics of the World Economy: 1-2008 AD, Maddison Project, 2011.

Meyerink, K. and L. Szucs, The Source: A Guidebook to American Genealogy, Provo, UT: Ancestry, 1984.

North, D., Institutions, Institutional Change and Economic Performance, Cambridge: Cambridge University Press, 1990.

Novais, F., Portugal e Brasil na crise do antigo sistema colonial (1777-1808), São Paulo: Hucitec, 1979.

Olsson, O. and D. Hibbs, “Biogeography and Long-Run Economic Development,” European Economic Review, 49(4): 909-938, 2005.

O’Rourke, K., "The Era of Free Migration: Lessons for Today”, IIIs Discussion Paper, \# 18, January, 2004.

Prado Jr., C., Formação do Brasil contemporâneo: colônia. 7.ed. São Paulo: Brasiliense, 1963.

Putterman, L. and D. Weil, "Post-1500 Population Flows and the Long Run Determinants of Economic Growth and Inequality”, Quarterly Journal of Economics, 125(4): 1627-1682, 2010.

Spolaore, E. and R. Wacziarg, "How Deep are the Roots of Economic Development," Journal of Economic Literature, 51(2): 325-369, 2013.

Thornton, R. "Population History of Native North American," in M. Haines and R. Steckel (eds.), Population History of North America, Cambridge: Cambridge University Press, 2000.

Vilela, A., "Exclusivo metropolitano, "superlucros" e acumulação primitiva na Europa pré-industrial," Topoi, 12(23): 4-29, 2011. 